\title{
A makroökonómiai dinamikák sokkal gyorsabban változhatnak, mint korábban gondoltuk
}

\author{
Stock, James H.: The Rate Debate - Rethinking Economics in the Age of Cheap Money. \\ Foreign Affairs, C. évf., 2021. 2. sz. pp. 174-184.
}

James H. Stock a Foreign Affairs 2020. március-áprilisi számában megjelent cikkében amellett érvel, hogy az elmúlt években az Egyesült Államokban zajló gazdasági változások szükségessé tették a közgazdaságtani modellek néhány központi elemének felülvizsgálatát. A szerző ezen megállapítását négy egymáshoz kapcsolódó fejleményből vezeti le: a természetes reálkamatláb csökkenéséből, a megújuló energiák árának eséséből, a tartósan 2\% alatti inflációból, illetve a CoVID-19 okozta gyors gazdasági összeomlásból és részleges felépülésböl.

Mérési módtól függetlenül megállapítható, hogy a természetes reálkamatláb ( $\left.\mathrm{r}^{*}\right)$ az Egyesült Államokban és más fejlett országokban körülbelül 1,5-2,5 százalékponttal csökkent az elmúlt két évtizedben. Ennek fő okai nem egyértelműek. Egyesek a gazdaságilag aktív népesség elöregedését, mások a magas kínai megtakarítási rátát hangsúlyozzák, valamint olyan tényezők is felmerülnek, mint a produktivitás alacsony növekedése, vagy a magas jövedelemkülönbségek. Bármi is az ok, ilyen alacsony r* mellett már nem biztos, hogy érvényes az a tétel, hogy a kormányzat nem halmozhat fel túl sok adósságot, mert az a kamatfizetések miatt adósságválságba taszítaná az államot. Amennyiben ugyanis a GDP növekedése meghaladja a kormányzat által fizetendő kamatot, úgy elméletben az adósságot a végtelenségig lehet görgetni, miközben az a GDP egyre kisebb hányadára csökken. Ezzel természetesen óvatosan kell bánni, ugyanis nem láthatjuk elöre, hogy mikor kerül a GDP növekedése az r* szintje alá, főleg úgy, hogy a természetes reálkamatláb csökkenésének nem ismerjük pontos okait.

A csökkenő r* a környezetvédelmi intézkedések jelenértékét is megnöveli, feltéve, hogy azt úgy mérjük, hogy a jelenben történő környezetszennyezést a jövőben okozott kár diszkontált értékével állítjuk szembe. Ennek számszerüsítésére az Egyesült Államokban kidolgoztak egy erre az elvre épülő mérőszámot, az SCC-t (Social Cost of Carbon), amely egy tonna szén-dioxid kibocsátás által okozott kár jelenértékét mutatja meg. Ha a természetes reálkamatláb értéke 3\%, akkor az SCC alapján jelenértéken 51\$-ba kerül $1000 \$$ kár elkerülése 2100-ban, ha azonban $\mathrm{r}^{*}=2 \%$-ra csökken, ez az összeg 125\$-ra nő. A környezetvédelem megtérülése csökkenő $r^{*}$ mellett jelenértéken mérve tehát egyre növekszik.

A közgazdászok a környezetvédelmi politikákat általában megtérülési oldalról közelítik meg, amire - az egységnyi szennyezés csökkentésének hasznát most konstansnak tekintve - kormányzati oldalról két módon lehet hatni: egyrészt a szennyezés költségének növelésével (például szénadó bevezetésével), másrészt a szennyezéscsökkentés költségének csökkentésével. A döntéshozók korábban általában előbbire koncentráltak, a zöld technológiák jelentős költségesése miatt azonban a fókusz kezd a második felé hajlani.

A szerző a Phillips-görbe felülvizsgálatának szükségességére is felhívja a figyelmet, amely a bérek növekedése és a munkanélküliség közötti negatív elöjelü összefüggést írja le, ugyanis az folyamatosan laposodik. Az 1990-es recesszió idején a munkanélküliségi ráta 1 százalékpontos növekedése még 0,8 százalékpontos inflációcsökkenést eredményezett, a 2000-es recesszió idején már csak 0,4-et, 2008-ban 0,3-at, 2020-ban pedig csupán 0,1 százalékpontosat - bár figyelembe kell venni, hogy a pandémia alatt az infláció mérése rendkívül nehéz volt például a fogyasztói kosarak gyors változása következtében. Az infláció stabilitására több lehetséges magyarázat létezik, például egyre több jószág és munkabér árszintjét határozza meg a nemzetközi környezet, és emiatt csökken érzékenységük a hazai változásra, vagy a stabil 
infláció a központi bankok sikerességének köszönhetö - bár ez felveti a kérdést, hogy miért nem sikerül sem a Fed, sem az EKB, sem a Bank of Japan számára az infláció 2\%-ra való növelése.

A szerző cikkének zárásaként még felhívja a figyelmet két dologra. Egyrészt arra, hogy bár a pandémia közben egyelőre nem láthatjuk tisztán, hogy az majd pontosan mit tanít nekünk, az már most biztossá vált, hogy a makroökonómiai dinamikák sokkal gyorsabban változhatnak, mint korábban gondoltuk. Másrészt arra, hogy a drámai változások ellenére a legtöbb modellünk jól müködött az elmúlt 5 évben is. Ezek közül kiemeli az externáliák koncepcióját, illetve azt az elméletet, miszerint a jól müködő gazdaság alapja egy jól müködő intézményrendszer.

Kiss Dávid ${ }^{1}$ : 